\title{
How 'direct' can a direct translation be? Some perspectives from the realities of a new type of church Bible
}

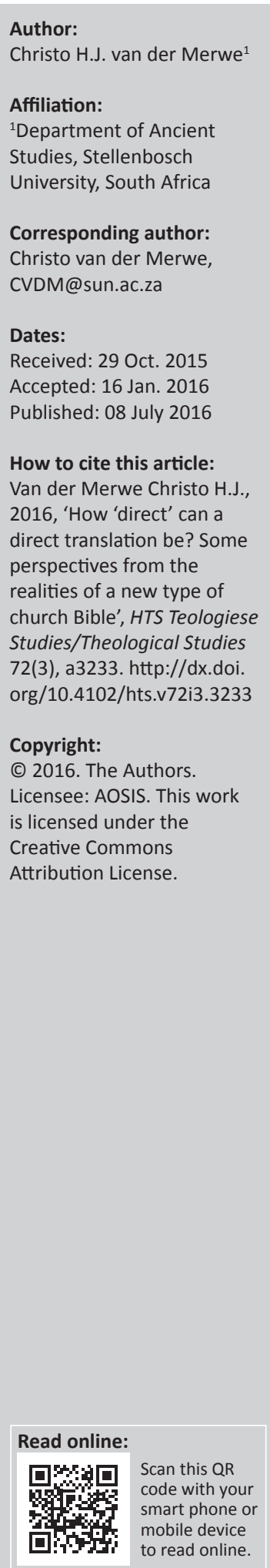

The skopos of this new type of church Bible is: 'How would the source texts of the Bible have sounded in Afrikaans in the context envisaged for its hypothesised first audience(s)?' Fully acknowledging the complexities of language as a dynamic and complex system embedded in the culture and conceptual world of its speakers, as well as the wide range of frames that are involved in the process of Bible translation as a difficult form of secondary communication, this article addresses two of the challenges of this ambitious project. In the first section the incongruence between the world of the Old Testament and speakers of Afrikaans is treated. Examples are provided of instances where both the nature of difficult secondary intercultural communication as well as the subjective theories of the host audience constrains the 'directness' of the translation. In the second section, some of the challenges of distinguishing between the formal and functional features of Biblical Hebrew are dealt with. The article concludes that, although the notion 'communicative clue' provides a useful heuristic device to act as point of departure for negotiations on the construal of the meaning of the text in the source language and host language respectively, the notion has to be supplemented by insights from the fields of cultural anthropology, cognitive linguistics and linguistic typology. A better understanding of how meaning 'works' (e.g. how linguistic expressions act as windows into the conceptual worlds of speakers, how the meaning of expressions may shift and develop, as well as processes of grammaticalisation) provides members of a translation team with some criteria to make informed decisions when they negotiate how the meaning of specific Biblical Hebrew constructions are to be construed 'directly' in Afrikaans.

\section{Introduction}

'Die Bybel. 'n Direkte vertaling' ('The Bible: a direct translation') is a new type of church Bible in the making that represents - after nearly five years of research and negotiations - a scholarly response to specific needs of more conservative churches that use the Bible in Afrikaans in South Africa and Namibia. The 'story' of this project is described in Van der Merwe (2012). ${ }^{2}$ The skopos of this Bible is that it is a 'direct translation'. In Van der Merwe (2014) it is illustrated that a 'direct' translation of the Bible is not new jargon for a word-for-word translation of the Bible. It is an attempt to 'interpretively resemble' in good idiomatic Afrikaans all the communicative clues of the source text in the contexts construed for the source text audience. This foreignising translation tries to let the Bible speak idiomatic Afrikaans in the time of the Bible. However, whenever the language structure and the conceptual world behind the language and culture of the source text could not be adequately understood and/or represented in the translation, or may be misunderstood by modern readers, additional information is provided in the paratext (e.g. introductions to the biblical books, maps, illustrations, footnotes and a glossary). Appiah (1993) calls this a 'thick translation'.

The model attempts to fully embrace the new horizons that have been opened in recent times by developments in both Translation Studies and Cognitive Linguistics. However, the notion 'direct translation' is a theoretical construct that operates with notions like 'authoritative source texts' and 'interpretive resemblance' (or 'directional equivalence' in the words of Pym 2010) that do not resonate well with most current Translation Studies scholars. ${ }^{3}$ Although it is indeed impossible to 1.The financial assistance of the National Research Foundation (NRF) of South Africa toward this research is hereby acknowledged.
Opinions expressed in this publication and the conclusions arrived at are those of the authors and are not necessarily to be attributed to the NRF.

2.See also Van der Merwe \& Basson (2003), Van der Merwe \& Van Rensburg (2007) and http://www.bybeldirektevertaling.co.za/ 3.Cf. e.g. Bassnett (2014). 
fully 'interpretively resemble' all the communicative clues of a source text in a 'direct translation', it is reasonable to argue that this neither renders the ideal invalid, nor makes it obsolete to explore strategies to come closer to the ideal (as expressed by the commissioners, the churches).

In the typical world of Bible translation, the authoritative role of the source language texts is not negotiable. According to Nord (2001), in commissioned translations, a translator has a multiple loyalty, on the one hand, towards the 'author(s)' of the source text, and on the other hand, the commissioner of the project. In the case of this project that represents a novel effort as far as the use of the notion 'direct translation' is concerned, it could be regarded as the professional duty of the translators ${ }^{4}$ to subject to scholarly scrutiny their proposed strategies to address the needs of their commissioner(s) on a continuing basis. The purpose of this paper is to make a contribution in this regard. It is hypothesised that a description of some of the typical examples of the challenges that need to be faced, the strategies that had been followed and the compromises that have appeared to be unavoidable, will contribute not only to more realistic expectations concerning what can and what cannot be accomplished when trying to make a 'direct translation' of the Bible; it will also profile the nature and extent of the information, knowledge and skills that are required and reveal some of the weaknesses and strengths of the strategies that have been opted for. These insights could be valuable for refinement of the translation model, as well as the training of Bible translation teams.

The article commences with a summary of the basic assumptions that undergird most of the strategies employed and translation solutions proposed. In the main section of the article I focus on what I regard as two of the major challenges of a direct translation, viz. the incongruence of the cultural frames of the source and host languages and that of distinguishing between the formal and functional features of the source text. Although only a few examples of these two challenges are treated, some tentative practical and theoretical conclusions are drawn from the practice of pursuing the lofty, but practically impossible, ideal that has been negotiated with the churches.

\section{Basic assumptions}

Not all the assumptions that are listed here have been explicitly described and/or documented in the run-up to this project, but most of them can be inferred from the parameters considered and the strategies that have been followed during the planning and implementation processes. ${ }^{5}$ While the first two assumptions listed here could be regarded as foundational, the second two are operational. For this reason the implementation of the latter assumptions had been influenced and informed by some of the challenges that arose in the course of the project.

\footnotetext{
4.The author of this article is part of the editorial committee of the Old Testament of this project. However, the views expressed (and interpretations made) in this pape are that of the researcher and not that of the Biblical Society of South Africa or that of the editorial committee of the project.
}

5.Cf. Van der Merwe (2012 and 2014).
Firstly, an interactional model of communication is assumed. ${ }^{6}$ In other words, a model of communication is used that acknowledges that the use of language in translation (as a form of communication) entails much more than the exchange of codes. The codes that are used in a source text are not only embedded in the conceptual worlds of those source language cultures, but are typically interpreted by readers in terms of their own conceptual worlds.

Secondly, Bible translation is an extremely complex form of secondary communication. ${ }^{7}$ It involves at least the sociocultural, organisational and speech situation frames of the source text and source language communities as well as those of the translator(s) and host language communities which are removed remotely from them in space and time. ${ }^{8}$

As far as the source language is concerned, the long and complicated transmission of the source text has led to many uncertainties concerning the source text that has to be translated. ${ }^{9}$ The limited corpus of Biblical Hebrew texts that are available also sometimes makes an adequate grammatical and lexical description of the various text types and diachronic phases of $\mathrm{BH}$ difficult. ${ }^{10}$ Even more complex is the identity and world of the source language communities whose conceptual worlds we try to reconstruct.

The host language audience - and by implication the commissioners of this translation - are primarily the members of more conservative churches who are used to the 1933/1953 word-for-word translation of the Bible in Afrikaans. Their basis for comparison (which will include English conservative translations), their views of what the Bible is for them and their expectations will need to be taken into account in the way in which translation problems are resolved. For this reason an explicit 'translation brief' was negotiated beforehand with the commissioners of this project. ${ }^{11}$ However, room had to be left for the fact that not all the expectations of all the intended readers of this translation would necessarily be captured by the translation brief. Furthermore, not all the implications of a 'direct translation' have necessarily been contemplated by both the translators as well as the churches in this pioneering project.

Thirdly, paratexts could be used to broaden the conceptual world of the readers, point out instances where the reading and/or interpretation of the source is problematic or could be misunderstood by readers. It has to be expected that the question of how much information had to be provided, where and in what format could be one of the major challenges of this project.

6.For more details about the interactional model, cf. Schiffrin (1994:397-405).

7.See Gutt (2000) in this regards.

8.See Wendland (2008) and Wilt and Wendland (2008).

9.See Tov (2001) and Khan (2013).

10.See Rezetko \& Young (2014) and Miller-Naudé \& Zevit (2012)

11.See Van der Merwe (2012) for more detail concerning the research that informed the negotiation process and details of the translation brief and skopus of the project. See also http://www.nuwekerkbybel.co.za. 
An important implication of the first three assumptions is that the responsibility for making the most justifiable choices for the perceived host audience rests heavily on the shoulders of the editorial committees. They have a deciding role in, (1) the construal of the meaning of the source texts in the contexts of the hypothesised 'first audience'; (2) the negotiation of how a perceived Afrikaans audience would have spoken Afrikaans in the context of the hypothesised 'first audience' and (3) the decisions of when and how the conceptual world of the host audience need to be enriched by paratextual means. In this process, each of the committees had to both 'probe into' and evaluate on a continued basis their own knowledge bases, preferences and points of view. For this purpose, despite its shortcomings, the notion of 'communicative clue' turned out to be useful.

Fourthly, Gutt's notion (2000) of 'communicative clue' could be used as a heuristic device. According to Gutt (2000:132-6) the 'communicative clues' from the source text are keys in the complex process of Bible translation. Communicative clues are, in the words of Hatim (2013:112), 'features built into the text for the purpose of guiding the audience to the intended interpretation. They are textual features which vary in degree of subtlety and which are perceived to be particularly significant for the intended meaning'.

In Van der Merwe (2014) it has been pointed out that some aspects of the communicative clues that Gutt distinguishes can be called into question. The main reason in this regard is that Gutt's theoretical model, Relevance Theory, is a theory of pragmatics. It focuses on how language is used, but does not provide much insight into how the meaning(s) of linguistic expressions emerge, change, may develop and are systematically related.

Nevertheless, cognitive semantics, which is compatible with many of Gutt's pioneering ideas, has opened new horizons on how the meaning of linguistic expressions work in language as a dynamic and complex system. ${ }^{12}$ Although aspects of this relatively recent paradigm that treats language as a window into the conceptual world of its users are still debated and many of its principles have not yet been applied widely in the description of the source languages of the Bible, a basic awareness of new insights of how meaning works and develops in language is demonstrating its value as this project advances. From the challenges described in the next section it will be clear that, although the notion of communicative clue is a useful heuristic device, the task of identifying and interpretively resembling covert communicative clues arising from the semantic representation' of the expressions (Gutt 2000:136) could be very complex. This will be the topic of the subsequent section. Also, fully understanding the function of overt communicative clues is not unproblematic, in particular distinguishing between expressions that encode a semantic value and those that are merely conventionalised formal features of the source text. Some examples in this 12.See Evans (2009) and Geeraerts (2010:182-287). regard are treated in the section on the formal and functional features of the source language.

\section{Challenges and proposed solutions}

This section focuses on the challenges and proposed solutions to interpretively resemble the source text in idiomatic Afrikaans - as if it was spoken in the time of the Bible. However, this translation is not prepared for an academic audience, and any proposed translation solution (and where relevant, also its paratext) cannot ignore 'subjective theories ${ }^{\prime 13}$ (e.g. what other translations its projected readers are used to, how they view Scripture, etc.). How this parameter influenced the translation solutions proposed will also be indicated below. $^{14}$

\section{Incongruent cultural frames}

It may be argued that proper names, geographical entities and artifacts which typically have unique referents, should be fairly straightforward. In a sense, this is indeed the case. However, the situation is also not always without its challenges.

Proper names like Jerusalem and Samaria do not pose a problem because both scholars and readers agree that their spellings are already entrenched in Germanic languages like Afrikaans and English. What did require some consideration is how proper names in general should be treated. Should they be translated or transcribed? If they are transcribed, which system of transcription should be used? In terms of the skopos of a 'direct translation', they should be transcribed, and where relevant provided with a translation in a footnote. However, it was asked whether new spellings would indeed contribute to the type of translation that the churches requested in a translation that is already foreignising in nature. Would technically 'correct' transcriptions not rather merely represent a scholarly zeal for consistency - a zeal that may even alienate some prospective readers? It was therefore decided that the spellings of proper names that readers have become used to in the 1983 translation of the Bible should be followed as far as possible. In cases where it could be argued that the understanding of the meaning of a place is relevant for the communication involved, a translation is provided in a footnote, e.g. in 1 Samuel 7:12, it is indicated that Eben-Haeser means 'klip van die hulp' ['stone of the help/assistance' $].{ }^{15}$

More problematic has been the translation of the names of God. While 'God' for 'elōhîm (אלֶים) is widely accepted, some prospective readers proposed that the 'real' name of $Y H W H$ (יהוֹ), namely 'Yahweh', should be used. Although it is technically speaking a more justifiable choice, it was argued

13.For the notion 'subjective theories' of readers, cf. Nord (2001).

14.The translations that are finalised by the editorial committee of the project, are submitted to a team of readers appointed by the churches who commissioned the translation. The translations are also posted on the website of the BSSA for any reader to comment on the proposed translation. The translations of the BDV that
are used in this article are therefore provisional.

15. In the headings of some psalms, musical terms, of which the meaning is uncertain,
have been transcribed. In a footnote a possible interpretation is given and/or it is have been transcribed. In a footnote a possible interpretation is given and/or it is
indicated that the meaning of the term is uncertain, e.g. Psalms 39:1, 42:1; 45:1. 
that, given the conservative nature of many of the prospective readers, it would be prudent not to try to change the name of 'the Lord' for conservative Christians. 'Here' (in small caps) was opted for. A section in a glossary is planned where the various translation options used for the names of God are explained. Particularly challenging in this regard were, 'e $\bar{l}-$

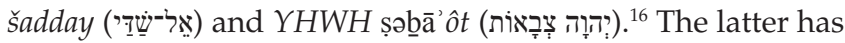
been translated in the KJV 'Lord of Hosts' and in some more recent translations as 'The Lord Almighty'. This practice was introduced by the Old Greek translation of 200 BCE and also adopted in the 1983 Afrikaans translation and some other modern English translations (e.g. NIV and the GNB). Since it was argued that the attribute 'Almighty' has too great a theological load and could lead to wrong (and sometimes) dangerous inferences by readers, it was decided that the equivalent of 'Almighty' should be avoided. On the basis of a small research project, ${ }^{17}$ a proposal to use the term 'die Heerser oor Alle Magte' ['the Ruler of All Powers'], was accepted. How this option will be accepted by the projected readers is an open question.

If one shifts to the referents of geographical spaces, one is confronted with the fact that the way in which cultures perceive and divide their environment differ. The labels they assign to the mental representations of their geographical environment differ and could easily be misunderstood and assigned inadequate or misleading translation equivalents.

If one considers the translation equivalent of the Hebrew

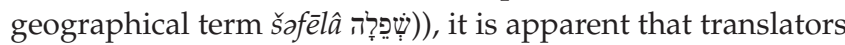
of modern English translations have not been very certain how to render this expression that refers exclusively to the low lying hill country west of the central Judean mountain range. Some translate it as 'the lowland' (ESV, NET, NJB, and NRSV), 'the western foothills' (NIV and CEB), 'the foothills to the west' (CEV), 'heuvelland' (NBV), while others render it as 'the shephelah' (NJPS and REB). Since this term is culturally specific, and refers only to the foothills to the west of the Judean mountain range, a 'direct translation' will have to follow the NJPS and REB and use the term 'the shephelah' with a footnote and/or glossary item to explain what the referent of the term is. ${ }^{18}$

Another apparently straightforward geographical lexical item for which the referent's conceptualisations in various contexts are often not certain, is the Hebrew lexeme nahal (נַ). The lexeme nahal occurs, according to a concordance search in Logos, about 137x in 119 verses of the Bible. In the NRSV, it is translated $66 \mathrm{x}$ as 'wadi,' $19 \mathrm{x}$ as 'valley,' $15 \mathrm{x}$ as 'stream' and $12 \mathrm{x}$ as 'torrent'. In the NIV it is translated $34 \mathrm{x}$ as 'valley,' 19x as 'stream,' $16 x$ as 'ravine,' $14 x$ as 'gorge,' $14 x$ as 'river' and 7x as 'wadi' (only in the phrase 'the wadi of 16.See also Van der Toorn, Becking and Van der Horst (1999).

17. How the names of God will be translated, in addition to a range of othe agreements on the translation of flora and fauna, the names of minerals, some key words, etcetra, have been 'provisionally' agreed upon and recorded at the outset of the project (as part of the translation brief).

18. Many translations do acknowledge the uniqueness of this term's referent (e.g. CEB, NIV, ISV and Elberfelder).
Egypt'). The translation value of the lexical item depends on which dimension, that is conceptual representation, of its semantic potential is profiled in each context of its use. It is possible that the difference in the translation equivalences referred to above reflects the translators' expert knowledge, or lack thereof, of the geography of Palestine. The reality that the features of a specific nahal changed over three millennia is, of course, also a parameter to be taken into consideration.

According to Snijders (1998:335-340), a nahal prototypically refers to a 'valley cut by a stream, often quite deep. The water, which runs down the mountains with great force during the rainy season ... carves a channel in the soil ... a nahal is a stream that flows only after rain, but then with great force and volume'.

To determine its translation value, we used the abovementioned definition as point of departure, but had to consider the contextual frames, as well as collocations of each of its uses.

So far we have made the following distinctions (which are also found in most BH lexical resources, for example Brown, Driver and Briggs [1907] and Koehler and Baumgartner [1999]):

1. Spruit (most English translations render here 'stream')

\begin{tabular}{|c|c|c|}
\hline & 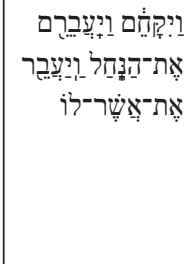 & $\begin{array}{l}\text { (BDV) Hy het hulle gevat en hulle deur } \\
\text { die spruit laat gaan en daarna ook wat aan } \\
\text { hom behoort, laat deurtrek } \\
\text { (NRSV) He took them and sent them } \\
\text { across the stream, and likewise everything } \\
\text { that he had (Gn. 32:23). }\end{array}$ \\
\hline
\end{tabular}

In these cases a footnote would be not necessary for speakers of Afrikaans since 'spruit' refers to what is prototypically referred to be means of nahal.

\section{Dal ('dale')}

\begin{tabular}{|c|c|c|}
\hline \multirow[t]{2}{*}{2} & 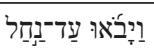 & (BDV) Toe hulle die Eskoldal bereik ${ }^{19}$ \\
\hline & אֶשְּּׁׁל & $\begin{array}{l}\text { When they reached the Eshcol dale } \\
(\mathrm{Nm} .13: 32) \text {. }\end{array}$ \\
\hline
\end{tabular}

We avoided an equivalent like 'valley' since it may invoke a conceptual representation of a luscious green flat area between two mountains for many modern Afrikaans readers. The translation of 'dal' ['dale'] could be regarded as neutral enough in this regard and may even render a footnote to explain the detail of the Hebrew equivalent superfluous.

\section{Rivierwilger ['river willow']}

\begin{tabular}{|c|c|c|}
\hline 3 & 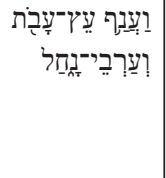 & $\begin{array}{l}\text { (BDV) die takke van welig groeiende } \\
\text { bome en rivierwilgers } \\
\text { branches of leafy trees, and river willows } \\
\left(\text { Lv 23:40). }{ }^{20}\right.\end{array}$ \\
\hline
\end{tabular}

19.cf. also Genesis 26:17; Numbers $21: 12$ and Deuteronomy 2:37.

20.Cf. also Leviticus 11:9. 
It could be argued that in \#3 the concrete conceptual representation of nahal is downplayed and only its metonymic association with something that contains water is profiled. No footnote would be needed to fully understand the utterances in which it is used. These two cases (\#2 and \#3) can, in terms of our cognitive semantic model, be regarded as non-prototypical, but plausible context-induced modulations of the typical conceptual representation of nahal.

Many other challenges for a direct translation can be attributed to the difference in the geographical space and physical environment of the source language and host language audiences, e.g. distinguishing between a mountain and a hill when the source language construction har (הר) can refer to both, or when the source language uses the notion of 'going up' or 'going down' and the host audience does not have a mental representation of the geography of SiroPalestine, etc.

As far as human-made things are concerned, a useful resource in Paratext often provided us the information needed to broaden the conceptual world of our host audience, e.g. the notion 'cistern' bôr (רiֹ ()), a pit dug out in rock used for storing water, in contrast to a 'well' bə' 'a deep construction, often walled with stone, at the bottom of which was a pool of water' (Pritz 2009:158-159). This referential information is needed to understand the use of

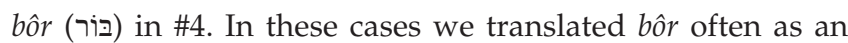
'opgaarput' ['storage pit'].

\begin{tabular}{|c|c|c|}
\hline 4 & 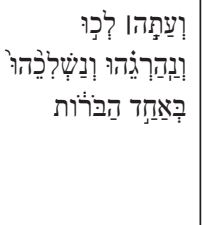 & $\begin{array}{l}\text { (BDV) Kom ons maak hom nou dood en } \\
\text { gooi hom in een van hierdie opgaarputte. } \\
\text { (NIV) Come now, let's kill him and } \\
\text { throw him into one of these cisterns (Gn } \\
37: 20) .{ }^{21}\end{array}$ \\
\hline
\end{tabular}

In a number of instances, it is evident that these 'cisterns' were also used as places where people were imprisoned (\#5).

\begin{tabular}{|c|c|c|}
\hline 5 & 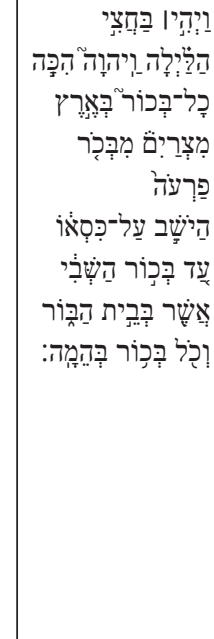 & $\begin{array}{l}\text { (BDV) Dit het teen middernag gebeur. } \\
\text { Die Here het alle eersgeborenes in } \\
\text { Egipteland getref, van die eersgeborene } \\
\text { van die farao wat op die troon gesit } \\
\text { het tot die eersgeborene van die } \\
\text { krygsgevangene in die ondergrondse } \\
\text { kelder, ook al die eersgeborenes van die } \\
\text { vee. } \\
\text { It happened at midnight, the Lord struck } \\
\text { down all the firstborn in the land of } \\
\text { Egypt, from the firstborn of Pharaoh } \\
\text { who sat on his throne to the firstborn of } \\
\text { the prisoner who was in the dungeon, } \\
\text { and all the firstborn of the livestock (Ex } \\
\text { 12:29). }{ }^{22}\end{array}$ \\
\hline
\end{tabular}

21.Also Genesis $37: 20,22,2428,29$; Exodus $21: 33,34$; Deuteronomy $6: 11$; 1 Samue 13:6; 19:22; 2 Kings 10:14; 18:31; 1 Chronicles 11:17, 18; 2 Chronicles 26:10; Nehemia 9:25; Ecclesiates 12:6; Isaiah 36:16; Jeremiah 2:13; $41: 7$ and 41:9.

22.Also Genesis 40:15; 41:14; Exodus 12:29; Jeremiah 2:13; 38:6, 7, 9,10,11, 13
From \#6, it appears as if one may deduce that these 'ondergrondse kelder' or 'kerkers' ['dungeons'] typically retained their function as constructions that collect water.

\begin{tabular}{|c|c|c|}
\hline 6 & 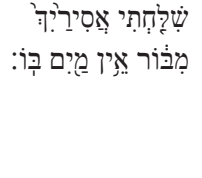 & $\begin{array}{l}(\mathrm{BDV}) \ldots \text { sal Ek jou gevangenes uit ' } \mathrm{n} \\
\text { waterlose opgaarput vrylaat } \\
\text {... I will set free your prisoners from a } \\
\text { waterless pit (Zch 9:11). } .^{23}\end{array}$ \\
\hline
\end{tabular}

This association of wetness and mud with bôr, is found also in \#7.

\begin{tabular}{|c|c|c|}
\hline 7 & 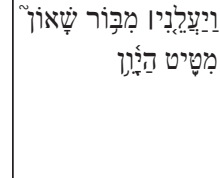 & $\begin{array}{l}\text { (BDV) Hy het my opgetrek uit die } \\
\text { dreunende put, uit die modderige slik. } \\
\text { (NIV) He lifted me out of the slimy pit, }{ }^{24} \\
\text { out of the mud and mire (Ps } 40: 3 \text { ). }\end{array}$ \\
\hline
\end{tabular}

In this latter case, bôr is now used to refer to the underworld although not always (Ps. 88:7, Pr. 28:17; Is. 14:19; Lm. 3:55; Ezk. 32:23) - but typically in the collocation 'die wat afdaal in

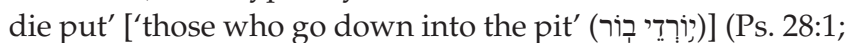
30:4; 88:5; Pr 1:12; Is 14:19; 38:18; Ezk. 26:20; 31:14,16; $32: 18,24,25,29,30)$.

Only the negative connotation of bôr is profiled in its nonprototypical use in \#8. Its role to refer to a construction to collect water, a place to keep prisoners or the underworld, is certainly downplayed here.

\begin{tabular}{|c|c|c|}
\hline 8 & 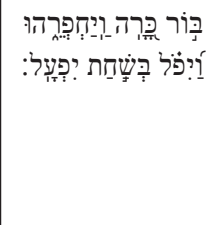 & $\begin{array}{l}\text { (BDV) Wie 'n put grawe en dit uithol, } \\
\text { val in die gat wat hy gemaak het } \\
\text { (ESV) He makes a pit, digging it out, } \\
\text { and falls into the hole that he has made } \\
\text { (Ps 7:16). }\end{array}$ \\
\hline
\end{tabular}

To these few relatively simple realia from the ancient world, one can add all the social conventions, as well as religious conventions and rituals that governed the life of the people of the biblical world. If one reads in Genesis 20:3 that Abraham

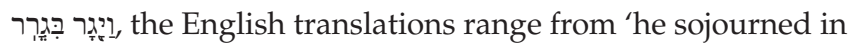
Gerar' (ESV); 'for a while he stayed in Gerar' (NIV); 'he lived as a temporary resident in Gerar' (NET); 'residing in Gerar as an alien' (NRSV); 'he settled as an immigrant in and Gerar' (CEB). Although it is obvious that Abraham stayed only for a short while in Gerar, the social conventions (e.g. of politeness) that govern the relationship between the sojourner and the local people, and in particular the chief or king of the area, are oblivious for the modern reader. Without additional information that supplements the use of the translation that is opted for, the notion 'immigrant'; 'alien'; 'outsider'; 'temporary resident' could easily be misunderstood. In South Africa, for example, it may be understood contextually as the Zimbabweans who take the jobs of the local people, etc. We opted for 'as vreemdeling vertoef' ['sojourned'] with a footnote for 'vreemdeling: 'Dit is 'n persoon wat om politieke of ekonomiese redes sy eie land verlaat het en tydelik in ' $n$ 23.Also Jeremiah 38:6.

24.The interpretation of the Hebrew equivalent of 'slimy' is uncertain. 
ander land woon. Vreemdelinge wat tydelike verblyf by die Israeliete gekry het, het beskerming geniet van die koning.' ['It is a person who, because of political or economic reasons, leaves his own land and resides temporarily in another land. Sojourners who got temporary residence from the Israelites enjoyed protection from the king.']. One may ask: Is this too much or too little additional information for the host audience? Is this footnote not misleading? For example, was the protection referred to not a general convention in the Ancient Near East? Furthermore, did the meaning of the term and the 'scripts and frames' associated with it not change over time? ${ }^{25}$ According to Kellerman (1977:446), in the priestly code, for example, a ger 'is largely regarded as a proselyte' living among Israelites.

The lexemes for 'cistern' and 'sojourner' exemplify how it is possible to reconstruct the prototypical mental representation of these lexemes in the Biblical world and to bring the conceptual world of modern readers through footnotes in line with that of the source text users. However, when one has to translate all the uses of the lexemes in the Bible, one is confronted with the reality that the concepts associated with these lexemes often change. However, our cognitive semantic model helps one to understand the processes of meaning extension involved and to postulate appropriate 'direct' translation equivalents with a degree of confidence. For example, in the case of both these lexemes, the extension came about through a cross-linguistically attested phenomenon called 'context-induced modulation'. Through its frequent use for a different purpose, the term for cistern also became the term for dungeon or prison. Although one has to be careful of semantic overloading, it is today widely acknowledged that lexemes may retain some associations of their earlier senses in new meanings and contexts of use. Consider how the referential realities of 'wetness' and 'muddiness' are retained when bôr refers to places of imprisonment and later even the realm of the underworld. However, in Psalm 7:16 - although admittedly a rare poetic use - most of these senses are downplayed; only some negative associations of a hole to cause somebody harm are retained. Here, one must keep in mind that poetic language often has an expressive function through defamiliarisation, that is only some associations of the mental representation of a lexeme may be profiled for a specific expressive purpose.

Similar challenges as those referred to in the above paragraph need to be addressed when linguistic expressions referring to other social conventions (e.g. the social stratification, the social functions and relationships among equals and unequals, sociolinguistics norms), other human-made artifacts, cultic terminology (e.g. rituals surrounding the offerings and cultic assemblies, the different types of offerings), conceptions of God, the cosmos and self, and the law codes need to be translated and supplemented with the relevant encyclopedic information. This represents one of the major challenges of a direct translation, viz. to find and establish the appropriate quality and quantity of the encyclopedic information that should be used to supplement translation choices concerning the cultural world of the Biblical Hebrew speakers in a particular text $\mathrm{x}$ at a hypothesised point $\mathrm{y}$ in history. At this stage of the project, the paratexts of the translation are, for all practical purposes, determined by the perceptions of the editorial committee concerning the assumed needs of the construed host audience(s). ${ }^{26}$

The challenge often deepens when theologically loaded abstract expressions have to be translated 'directly'. A good example is the Hebrew lexeme hesed (דֶ) (The NRSV translates the lexeme typically with 'steadfast love,' but also often with 'love', 'loving kindness', 'kindness,' 'loyalty,' 'faithfulness,' 'mercy' and 'good deeds.' We opted so far typically for 'troue liefde' which is close to the 'steadfast love' of the NRSV. However, the question is, can a specific 'scholarly justified' range of apparently clear translation equivalents broaden the conceptual world of modern readers sufficiently to appreciate its semantic potential and uses? In order that they, on the one hand, do not semantically overload the term in some contexts, but, on the other hand, also do not fail to grasp the theological connotations it conveyed for the speakers in other speech frames, I hypothesise that a glossary item would be needed with the following type of information:

The expression occurs 245x in the Hebrew Bible, of which 127 instances are in the Psalms. Although it has a predominantly theological use (i.e. $75 \%$ of its occurrences), its roots are most probably secular. In particular, it refers to the reciprocal goodwill and loyalty which members of the same extended family were to show towards one another in order to survive in the harsh environment in which they lived. It was an attitude that was not primarily concerned with affection, but with deeds of kindness and loyalty. Outside the realm of the family (between friends, allies, a ruler and his subjects), its reciprocal nature was often sealed with an oath or formal agreement (or 'covenant') between the individual parties. When used as an attitude of God towards humans, the reciprocal nature of the loving kindness is typically downplayed. It is part of God's nature to manifest it in abundance; it is often described as the ground of His conduct towards His people and it has an enduring quality to it. From its use in some contexts, it appears that, in time, it has acquired a moral character. Humans need to show one another loving kindness since this is the right thing to do and, after all, they receive it in abundance from God. ${ }^{27}$

\section{Formal and functional features of the source language}

It is beyond the scope of this article to elaborate on all the formal features of Biblical Hebrew as a Semitic language, for example that it is a VO language, that it has almost no 'case markings', its verbal system is, morphologically speaking, relatively simple, etc. I will concentrate on only a few issues in this regard.

\footnotetext{
26. Feinauer investigates the use of glossaries in literary texts and points out that very little is said about the use of glossaries in theories of translation (2015.5). It is reasonable to infer that this observation applies also to the use of paratext in general.
}

27.Cf. Zobel (1988:44-64). 
It is, for example, well-known that Biblical Hebrew is a paratactic language, and it accordingly abounds with the use of the equivalent of 'and', viz. waw - which occurs more than 50000 times in the Hebrew Bible. Consider the following example from Genesis 24:15.

\begin{tabular}{|c|c|c|}
\hline 9 & 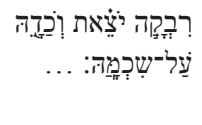 & $\begin{array}{l}\text { Rebekah came out ... (and) with her } \\
\text { water jar upon her shoulder (Gn } \\
\text { 24.15). }\end{array}$ \\
\hline
\end{tabular}

It would not be idiomatic Afrikaans to render the waw with 'en' ['and']. In such a case, the translation equivalent 'met' ['with'] will be a perfectly natural 'direct' translation of waw.

When we consider how prepositions are sometimes used in this ancient language, the situation becomes more of a challenge. Studies in the field of grammaticalisation have shown that prepositions often originate from body parts (cf. the English preposition 'back'). ${ }^{28}$ Furthermore, most uses of prepositions can be traced back to their primary spatial proto scenes (cf. the English preposition 'in' and how its path of development can be traced from space 'he lives in the country' to time 'he came in the morning'). ${ }^{29}$ However, prepositions often tend to lose their semantic value and become grammatical markers (i.e. they function like case markers that indicate the grammatical role of a constituent). ${ }^{30}$ In the course of our project, we have been challenged by the preposition $\min$ (מ̣) in Genesis 11:2 (\#11). ${ }^{31}$ The prototypical function of the preposition min is movement in space of an entity $\mathrm{x}$ away from a landmark $\mathrm{y}$ (detachment from a point in space like in \#10).

\begin{tabular}{|c|c|c|}
\hline 10 & 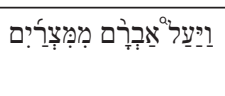 & $\begin{array}{l}\text { Abraham went up from Egypt } \\
\text { (Gn 13:1). }\end{array}$ \\
\hline
\end{tabular}

If one considers \#11 however, we find conflicting translations, even among the more conservative translations.

\begin{tabular}{|c|c|c|}
\hline 11 & 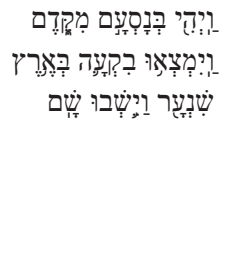 & $\begin{array}{l}\text { (ESV) And as people migrated from } \\
\text { the east, they found a plain in the } \\
\text { land of Shinar and settled there } \\
\text { (NIV) As people moved eastward, } \\
\text { they found a plain in Shinar and } \\
\text { settled there (Gn 11:2). }\end{array}$ \\
\hline
\end{tabular}

A small research project to establish if and how this preposition shifted - actually reversed - its meaning, led to the conclusion that this is indeed the case. Examples like \#12 and \#13 are regarded as evidence that the preposition sometimes completely loses its semantic 28.Cf. Kraska-Szlenk (2014). 29.See also Tyler and Evans (2003) and Lyle (2013).

30.See Hardy (2014).

31.Wenham (1998:233) remarks on this verse: G, Vg take מקדם as"from the East," but many modern commentators cite 13:11 in support of translating it 'eastward'. The former translation is more natural, but clearly the issue depends on where the people are supposed to have come from before arriving in Babylon: 'in the East' leaves the issue undecided.

Cf. also Sarna (1989:81) and Westermann (1994:533). value 'detachment from a spatial position', or gains from its context the value of 'orientation towards a lexically specified direction' ${ }^{32}$

\begin{tabular}{|c|c|c|}
\hline 12 & 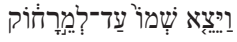 & His fame spread far. (2 Chr. 26:15) \\
\hline 13 & 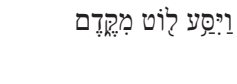 & $\begin{array}{l}\text { Lot then journeyed eastward } \\
(\mathrm{Gn} .13: 11) .{ }^{32}\end{array}$ \\
\hline
\end{tabular}

Since, in the case of \#13, readers of the Afrikaans Bible will encounter both translations, we include, like the NIV and CEB, a footnote that the expression miqqedem (מָקִ is also translated as 'uit die ooste' ['from the east'].

A maxim of cognitive linguistics is that the meaning we construct in and through the language is not a separate and independent module of the mind, but it reflects our overall experience as human beings,' and this notion 'is sometimes formulated by saying that meaning is experientially grounded - rooted in experience' (Geeraerts 2006:5). Although cultures differ in how they 'cut up' and name their bodies - and the entire world around them - (Riemer 2010:390-392), there is evidence of common patterns in how the body is used as a source for other concepts - in other words, how meanings are extended (Kraska-Szlenk 2014:16). These processes of meaning extension accord with the growing body of knowledge of figurative language, which, according to Dancygier and Sweetser (2014:1), is 'part of the basic fabric of linguistic structure'. Since a cognitive semantic perspective of how meaning works underpins our notion of a 'direct' translation, I will consider now some examples of how we approached the body part, yād (יז), which is typically translated 'hand'. Although it will again confirm the complexity of the challenges of the skopos of this translation, it will also demonstrate that our perspective of how meaning works does provide some guidance for finding translation solutions that interpretively resemble the source text in a more justifiable way than others.

If one considers how this body part is used, the following picture emerges $^{33}$ : It could be used as a body part to carry out an everyday function \#14, it could be used in a cultural specific symbolic act, i.e. the taking of a pledge (\#15), and it could be used in the figurative senses in which the functional aspects associated with the literal body part are profiled (\#16-18). From the examples below, it is evident that a particular functional aspect of the body part may lead to expressions in Biblical Hebrew for which it is possible to find 'direct' equivalents (\#14), or equivalents with similar 'body-part-related' conceptualisations (\#15-18) in Germanic languages such as Afrikaans and English. However, there are also cases where it is difficult (\#19) or nearly impossible (\#20) to find body-part-related equivalents. In other words, the equivalent of 'hand' in the source language has to give 32.Exodus 14.19; Isaiah 17.13; $22.3 ; 57.9$

33.Some of the examples are from Wagner (2014:10). 


\begin{tabular}{|c|c|c|}
\hline 14 & 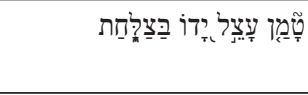 & $\begin{array}{l}\text { The lazy person buries his } \\
\text { hand in the dish (Pr. 26:15). }\end{array}$ \\
\hline 15 & 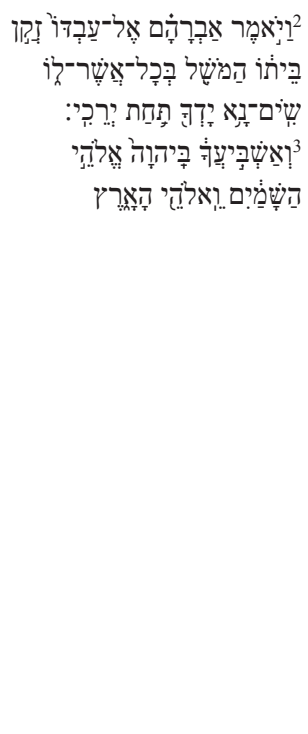 & $\begin{array}{l}\text { (NRSV) }{ }^{2} \text { Abraham said to } \\
\text { his servant, the oldest of his } \\
\text { house, who had charge of } \\
\text { all that he had, 'Put your } \\
\text { hand under my thigh }{ }^{3} \text { and I } \\
\text { will make you swear by the } \\
\text { Lord, the God of heaven } \\
\text { and earth, } \\
\text { (BDV) Eendag sê Abraham } \\
\text { vir die oudste dienaar in sy } \\
\text { huis, die een wat beheer } \\
\text { gehad het oor al sy besittings: } \\
\text { Plaas tog jou hand onder my } \\
\text { heup, }{ }^{3} \text { sodat ek jou by die } \\
\text { Here, die God van die hemel } \\
\text { en die aarde, 'n eed kan laat } \\
\text { sweer (Gn } 24: 2-3 \text { ). }{ }^{34}\end{array}$ \\
\hline 16 & 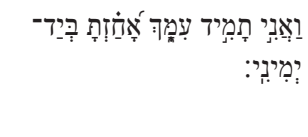 & $\begin{array}{l}\text { (ESV) Nevertheless I am } \\
\text { continually with you; you } \\
\text { hold my right hand (Ps. } 73: 23 \text { ). }\end{array}$ \\
\hline 17 & 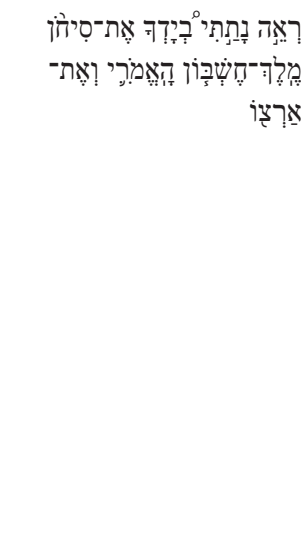 & $\begin{array}{l}\text { (ESV) Behold, I have given into } \\
\text { your hand Sihon the Amorite, } \\
\text { king of Heshbon, and his } \\
\text { land. } \\
\text { (NRSV) See, I have handed } \\
\text { over to you King Sihon the } \\
\text { Amorite of Heshbon, and his } \\
\text { land. } \\
\text { (NJPS) See, I give into your } \\
\text { power Sihon the Amorite, } \\
\text { king of Heshbon, and his } \\
\text { land (Dt. 2:24). }\end{array}$ \\
\hline 18 & 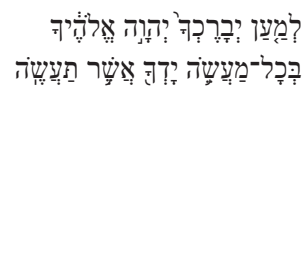 & $\begin{array}{l}\text { (NRSV) ...so that the Lord } \\
\text { your God may bless you in all } \\
\text { the work that you undertake. } \\
\text { (BDV) sodat die Here jou } \\
\text { God jou kan seën in alles wat } \\
\text { jy aanpak (Dt. 14:29). }\end{array}$ \\
\hline
\end{tabular}

way to 'power' in order to be regarded as good idiomatic English or Afrikaans. While it could be argued that, in the case of \#19, a note should have been used to explain that $y \bar{a} d$ may refer to the paw, and by implication claw, of an animal, a note in \#20 would not enrich the conceptualisation of the image that is used there.

Apart from collocations like \#20, where it could be argued that $y \bar{a} d$ acquired the sense of 'power', linguistic typological evidence led us not to 'over-translate' instances like those we found in \#21-26.

34.The following note is supplied in the DBV: "Hierdie simboliese handeling het die eed bekragtig' [The symbolic action validated the oath].

\begin{tabular}{|c|c|c|}
\hline 19 & 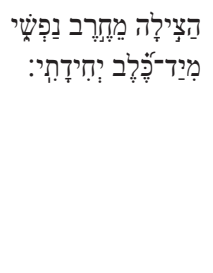 & $\begin{array}{l}\text { (NRSV) Deliver my soul from the } \\
\text { sword, my life from the power of the } \\
\text { dog! } \\
\text { (BDV) Red tog my lewe van die } \\
\text { swaard, my enigste lewe uit die mag } \\
\text { van die hond (Ps. 22:21). }\end{array}$ \\
\hline 20 & 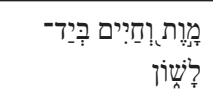 & $\begin{array}{l}\text { (ESV) Death and life are in the power } \\
\text { of the tongue (Pr. 18:21). }{ }^{35}\end{array}$ \\
\hline 21 & 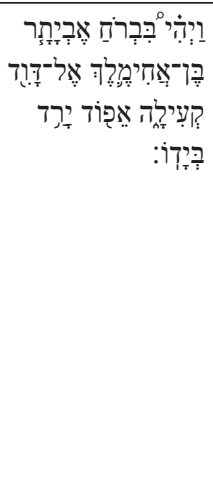 & $\begin{array}{l}\text { (ESV) When Abiathar the son of } \\
\text { Ahimelech had fled to David to } \\
\text { Keilah, he had come down with an } \\
\text { ephod in his hand. } \\
\text { (NIV) Now Abiathar son of Ahimelek } \\
\text { had brought the ephod down with } \\
\text { him when he fled to David at Keilah. } \\
\text { (BDV) Toe Abjatar, seun van } \\
\text { Agimelek, na Dawid in Keila gevlug } \\
\text { het, het hy afgegaan met die efod by } \\
\text { hom (1 Sm. 23:6). }\end{array}$ \\
\hline 22 & 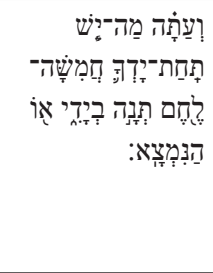 & $\begin{array}{l}\text { (NRSV) Now then, what have you at } \\
\text { hand? Give me five loaves of bread, } \\
\text { or whatever is here. } \\
\text { (BDV) En nou, wat het u beskikbaar? } \\
\text { Vyf brode? Gee dit vir my; of wat u } \\
\text { ook al het (1 Sm. 21:4). }\end{array}$ \\
\hline 23 & 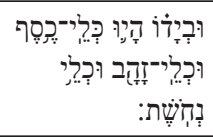 & $\begin{array}{l}\text { (ESV) And Joram brought with him } \\
\text { articles of silver, of gold, and of } \\
\text { bronze ( } 2 \mathrm{Sm} .8: 10) \text {. }\end{array}$ \\
\hline 24 & 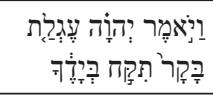 & $\begin{array}{l}\text { (ESV) And the Lord said, 'Take a } \\
\text { heifer with you.' (1 Sm. 16:2). }{ }^{36}\end{array}$ \\
\hline 25 & 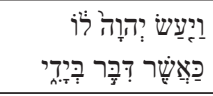 & $\begin{array}{l}\text { (ESV) The Lord has done to you as } \\
\text { he spoke by me ( } 1 \mathrm{Sm} \text {. 28:17). }\end{array}$ \\
\hline 26 & 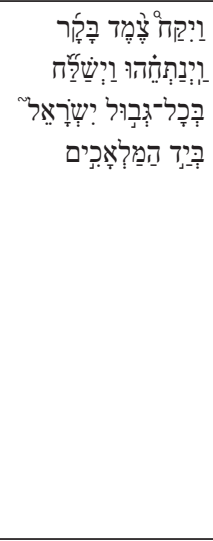 & $\begin{array}{l}\text { (ESV) He took a yoke of oxen and cut } \\
\text { them in pieces and sent them } \\
\text { throughout all the territory of Israel } \\
\text { by the hand of the messengers. } \\
\text { (NRSV) He took a yoke of oxen, and } \\
\text { cut them in pieces and sent them } \\
\text { throughout all the territory of Israel } \\
\text { by messengers. } \\
\text { (BDV) Hy neem toe twee osse, kap } \\
\text { hulle op en stuur dit met boodskappers } \\
\text { deur die hele gebied van Israel met die } \\
\text { woorde: (1 Sm. 11:7). }\end{array}$ \\
\hline
\end{tabular}

However, there is a very fine line between an over- and under-translation. In the case of \#27 it could be argued that an apparent 'grammaticalised' body part rather requires a different body part in the Afrikaans. ${ }^{37}$

35.cf. also 2 Sameul 8:3.

36.Cf. 1 Samuel 9:8.

37.Most English translations do not opt for the 'other' body part 'mouth'. Cf. the ESV in \#27, also the NKJV, NASB, NRSV and NIV. 


\begin{tabular}{|c|c|c|}
\hline 27 & 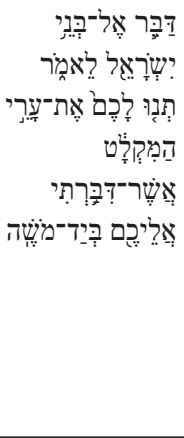 & $\begin{array}{l}\text { (BDV) Praat met die Israeliete en sê, } \\
\text { 'Julle moet vir julleself die asielstede } \\
\text { daarstel wat Ek vir julle deur by monde } \\
\text { van Moses aangewys het.' }{ }^{38} \text { [Speak to } \\
\text { the Israelites and say, 'You must set up } \\
\text { for yourself the refuge cities which I } \\
\text { pointed out to you by mouth of Moses. } \\
\text { (ESV) Say to the people of Israel, } \\
\text { 'Appoint the cities of refuge, of which I } \\
\text { spoke to you through Moses, (Jos. 20:2). }{ }^{39}\end{array}$ \\
\hline
\end{tabular}

In cognitive linguistic circles it is widely acknowledged that linguistic communication typically does not involve only the exchange of the propositional content concerning objects, situations and events in the world. A crucial aspect of communication process is what Langacker (2008:73-78) calls the 'viewing arrangement' between speakers and hearers of their conceptualisations of the world. In a direct translation an attempt is made to retain those viewing arrangements, e.g. the level of specificity, the figure-ground alignment and the subjective perspectives of speakers and authors. ${ }^{40} \mathrm{We}$ will touch here only on the notion of 'level of specificity'.

An important feature concerning the treatment of proper names in a 'direct translation' is the way in which they are presented, and in particular, apparently 'unnecessarily

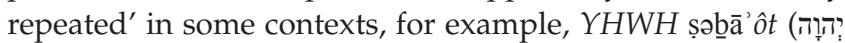
צִבְָאוֹ), 'Ruth, the Moabite' (in the book of Ruth) ${ }^{41}$, 'David, the king', etc. In some instances, experts in Afrikaans literature and language objected that this type of redundant overspecification does not represent good idiomatic Afrikaans. In most of these cases, however, a consensus has been reached that these instances of over-specification were significant

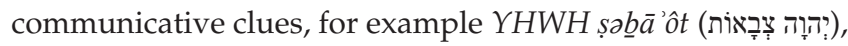
is typically present in contexts where God's feature as a warrior who fights on behalf of the cause of His people is profiled. ${ }^{42}$ The 'overuse' of this way of referring to God in Haggai, Zechariah and Malachi, at a time when His people were, politically and military, speaking completely insignificant, without doubt was used to encourage and convince some readers who were confronted with the realities of their dire situation just after the exile. ${ }^{43}$

It has to be acknowledged that very few translations of Haggai do not maintain their equivalent of the repetitive use

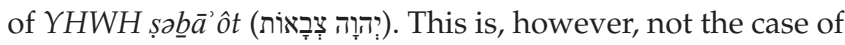
referring to David as 'David, the king' in the context where 38.The NBV also reads "by monde van'.

39.Cf. also Exodus 9:35 and Numbers 27:23.

40.For an investigation of some the implications of these viewing arrangements for the translation of a secular poem, cf. Tabakowska (2013:229-250).

41.Ruth $1: 22 ; 2: 2,21 ; 4: 5$ and 10 . Most scholars have no doubt that this way of representing of Ruth's acts as a significant communicative clue in the book of Ruth, cf. Bush (1998:24); LaCocque (2004:58).

42.Cf. Van der Woude (1997:1042).

43.The expression יהוה צבבאוֹ occurs 240x in the Hebrew Bible. Van der Woude (1997:1041) remarks: 'The concentration of the divine designation shortly after the exile is remarkable (Hag., Zech., Mal.)' - in particular if one considers it occurs only once in 'late OT literature'. the referent David is already discourse active as 'David' and as 'the king'; cf. \#28 in the context of 2 Samuel 16:1-5:

\begin{tabular}{|c|c|}
\hline 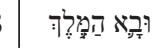 & (NRSV) When King David came to Bahurim \\
\hline דִּרוד & (NJB) As David was reaching Bahurim \\
\hline $1: 111 \frac{1}{\tau}$ & (CEV) David was near the town of Bahurim \\
\hline
\end{tabular}

In Runge (2007) it was established that these types of overspecialisation typically have a rhetorical function that could not be ignored. In the case of \#28, the text gets an ironic ring when David is portrayed as 'King David' when he is abandoning his royal city in order to flee from his own son.

\section{Conclusion}

In this presentation, the question 'How direct can a "direct" translation be?' served to prompt the aim of this study, that is to illustrate that this skopos is indeed an ambitious attempt to address the specific needs for churches in Southern Africa that want 'a clearly understandable, sourcetext-oriented Afrikaans translation'. Its own theoretical foundation acknowledges the complexity of language as a dynamic and complex system and the subsequent impossibility to meet all the expectations of the communal commissioner. We have to concur with Pym (2010:41) that, as a type of directional equivalent translation, it represents a 'shared illusion'. Nevertheless, it represents the most 'costeffective' strategy for the purposes of this specific instance of cross-cultural communication; this is because its cognitive linguistic points of departure open up a promising range of new horizons for the translation of the Bible (and for that matter any ancient text) at a time when knowledge is exploding and book technology is giving way to hypertext technology. ${ }^{44}$

From the examples and processes we discussed, the following became apparent:

- The notion 'communicative clue' has been a useful heuristic device. However, the construal of many communicative clues requires insight into how the meaning of linguistic expressions 'works'. A specific linguistic expression typically may acquire different senses. In the case of an ancient language, to establish with a degree of confidence which sense is involved and when, can sometimes be a daunting task, in particular if the available lexica merely provide a taxonomy of translation equivalents. In recent times, cognitive semantics has shed some light on how these senses develop across languages, for example from specific to generic (e.g. bôr and nahal). In the case of prepositions, a specific spatial sense may even get lost and the preposition may acquire a generic grammatical function (e.g. $\mathrm{min}$ ). Body parts are often prominent in figurative extensions. Although they typically retain aspects of their functional dimension of use, they too are prone to acquire new lexical senses (typical via their functional dimension of use) or become semantically schematic (e.g. yād).

44.Cf. Van der Merwe (2006) 
- The 'viewing arrangements' - as communicative clues of specific speakers and authors, and conventions of source and host language communities, are crucial parameters to consider if a translation strives to be 'direct,' (e.g. in the case of the over-specification of referents).

- Because many communicative clues cannot be interpretively resembled by means of a translation equivalent in Afrikaans, the conceptual world of the modern readers needs to be enriched by means of a paratext. When and how the conceptual world of specific modern readers needs to be broadened is not always certain and therefore requires more research. However, the value and role of the paratext for developing a greater appreciation of the otherness of the ancient text as well as a better understanding thereof cannot be disputed (e.g. the shephelah).

- The notion of 'communicative clue' could often be used as point of departure in the negotiation process between the source and host language members of the translation team. The negotiation process benefitted much by the following three considerations: Firstly, the role of the host language experts of the team is acknowledged as pivotal in all stages of the project; in other words, the host language members of the team are not merely editors to 'polish' the style of the translation. Secondly, all members of the team are aware that some of their construals of how the communicative clues should be interpretively resembled are tentative and need to be more fully researched. Thirdly, translations or conventions that conservative Bible readers are used to, may sometimes override 'scholarly', more justifiable translation options (e.g. the spelling of names and the names of God).

At a time when donors call for the acceleration of the pace of Bible translations, the challenges of a direct translation again reveal how much we need to know, how little we really know, and how much there is still to find out. This opens new horizons, and of course, challenges, for Bible translation scholars, for example, (1) it encourages them to be more realistic when spelling out to churches the implications of their expectations to have Bible translations that 'are as close to the source text as possible'; (2) it contributes to a greater appreciation of the urgent need for wide-ranging research projects on the conceptual world of the Bible; (3) it exposes the need for the effective and user-friendly integration of this new knowledge with existing information in the electronic resources that are used by translation teams ${ }^{45}$ and (4) it contributes to a greater appreciation of the need for effective training courses for Bible translation teams in how meaning 'works'.

45.In recent years some fascinating information also from the fields of anthropology and iconography has shed new light on the use of some aspects of the figurative language and meaning of the Biblical Hebrew source text (Staubli \& Schroer 2014). New light has also been shed on the interpretation of many other overt 'communicative clues', that is discourse particles (Miller-Naudé \& Van der Merw 2011), on the interpretation of word order in Biblical Hebrew (Van der Merwe an Wendland 2010), as well as the interpretation of the Hebrew verbal system (Andrason 2011). However, few of these insights have yet found their way into current translations.

\section{Acknowledgements Competing interests}

The author declares that he has no financial or personal relationships which may have inappropriately influenced him in writing this article.

\section{References}

Andrason, A., 2011, 'The Biblical Hebrew verbal system in light of grammaticalization the second generation', Hebrew Studies 53, 351-383. http://dx.doi.org/10.1353/ hbr.2011.0010

Appiah, K.A., 1993, 'Thick translation', in L. Venuti (ed.), The translation studies reader, pp. 417-429, Routledge, London.

Bassnett, S., 2014, Translation, Routledge, New York, NY.

BDV, forthcoming, Die Bybel: ' $n$ direkte vertaling, Bybelgenootskap van Suid Afrika, Bellville.

Brown, F., Driver, S.R. \& Briggs, C.A., 1907, A Hebrew and English lexicon of the Old Testament, Clarendon Press, Oxford.

Bush, F.W., 1998, Ruth, Esther, Word Books, Dallas, TX. (WBC 9).

CEB, 2011, Common English Bible, Common English Bible, Nashville, TN.

Dancygier, B. \& Sweetser, E., 2014, Figurative language, Cambridge University Press, Cambridge.

Elberfelder, 1985, Die Bibel, Elberfelder Übersetzung, Revidierte Fassung, R. Brockhaus Verlag, Wuppertal.

ESV, 2001, The Holy Bible: English Standard Version, Standard Bible Society, Wheaton, IL.

Evans, V., 2009, How words mean: Lexical concepts, cognitive models, and meaning construction, Oxford University Press, Oxford.

Feinauer, A.E., 2015, 'n Taalkundige kyk na glossariums in literêre vertaalprodukte, SUN Media, Stellenbosch.

Geeraerts, D., 2006, Cognitive linguistics: Basic readings, De Gruyter Mouton, New York, NY.

Geeraerts, D., 2010, Theories of lexical semantics, Oxford University Press, Oxford.

GNB, 1992, The Holy Bible: The Good News translation, 2nd edition, American Bible Society, New York, NY.

Gutt, E.-A., 2000, Translation and relevance. Cognition and context, 2nd edn., St Jerome Publishing, Manchester, Boston, MA.

Hardy, H.H., 2014, 'Diachronic development in Biblical Hebrew prepositions: A case study in grammaticalization', PhD dissertation, Department of Near Eastern Languages and Civilizations, University of Chicago, Chicago, IL.

Hatim, B., 2013, Teaching and researching translation, Pearson, London.

ISV, 2011, International Standard Version, ISV Foundation, Yorba Linda, CA.

Kellerman, D., 1977, 'רוֹ gûr', in G. J. Botterweck \& H. Ringgren (eds.), Theological dictionary of the Old Testament, , vol. II, transl. J.T. Willis, pp. 439-449, Eerdmans, Grand Rapids, MI.

Khan, G., 2013, A short introduction to the Tiberian Masoretic Bible and its reading tradition, Gorgias Press, Piscataway, NJ.

KJV, 2009, The Holy Bible: King James Version, (Electronic version of the 1900 Authorized Version), Logos Research Systems, Bellingham, WA

Koehler, L. \& Baumgartner, W., 1999, The Hebrew and Aramaic lexicon of the Old Testament; subsequently revised by Walter Baumgartner and Johann Jakob Stamm, Eerdmans, Grand Rapids, MI.

Kraska-Szlenk, I., 2014, 'Semantic extensions of body part terms: Common patterns and their interpretation', Language Sciences 44, 15-39. http://dx.doi. org/10.1016/j.langsci.2014.02.002

LaCocque, A., 2004, Ruth, Fortress Press, Minneapolis, MN. (A Continental Commentary).

Langacker, R.W., 2008, Cognitive grammar: A basic introduction, Oxford University Press, Oxford.

Lyle, K.A., 2013, 'A new methodology for ascertaining the semantic potential of Biblical Hebrew prepositions', Hebrew Studies 54, 49-67. http://dx.doi. org/10.1353/hbr.2013.0012

Martin, R.M., 2013, 'More than a way with words: The interface between cognitive linguistics and cognitive translatology', in A. Rojo \& I. Ibarretxe-Antuñano (eds.) Cognitive linguistics and translation: Advances in some theoretical models and applications, pp. 75-97, De Gruyter Mouton, Berlin.

Miller-Naudé, C.L. \& Van der Merwe, C.H.J., 2011, 'הֵּה a and mirativity in Biblical Hebrew', Hebrew Studies 52, 53-81. http://dx.doi.org/10.1353/hbr.2011.0017

Miller-Naudé, C.L. \& Zevit, Z. (eds.), 2012, Diachrony in Biblical Hebrew, Eisenbrauns, Winona Lake, IN.

NASB, 1986, New American Standard Version, The Lockman Foundation, LaHabra, CA

NBV, 2004, De Nieuwe Bijbelvertaling, Nederlands Bijbelgenootschap, Haarlem.

NET, 2005, The Net Bible, New English Translation, Biblical Studies Press, www. netbible.com 
NIV, 2011, New International Version, 4th edn., Zondervan, Grand Rapids, MI.

NJB, 1985, New Jerusalem Bible, Doubleday, New York, NY.

NJPS, 1997, Tanach: The Holy Scriptures, (Electronic version of 1985 edition), Jewish Publication Society, Philadelphia, PA.

NKJV, 1982, New King James, Thomas Nelson, Nashville, TN.

NLT, 2007, Holy Bible: New Living Translation, Tyndale Publishing House, Carol Stream, IL.

Nord, C., 2001, 'Loyalty revisited: Bible translation as a case in point', The Translator 7 , 185-202. http://dx.doi.org/10.1080/13556509.2001.10799100

NRSV, 1989, The Holy Bible: New Revised Standard Version, Thomas Nelson, Nashville, TN.

Pritz, R., 2009, The works of their hands: Man-made things in the Bible, United Bible Societies, New York, NY. (Helps for Translators)

Pym, A., 2010, Exploring translation theories, Routledge, New York, NY.

Rezetko, R. \& Young, I., 2014, Historical linguistics and Biblical Hebrew: Steps toward an integrated approach, Society of Biblical Literature, Atlanta, GA.

Riemer, N., 2010, Introducing semantics, Cambridge University Press, Cambridge.

REB, 1989, Revised English Bible, Oxford University Press, Oxford.

Runge, S.E., 2007, 'A discourse-functional description of participant reference in Biblical Hebrew narrative', PhD dissertation, Department of Ancient Studies, Stellenbosch University.

Sarna, N.M., 1989, The JPS Torah commentary: Genesis, Jewish Publication Society, Philadelphia, PA. (The JPS Torah Commentary).

Schiffrin, D., 1994, Approaches to discourse, Blackwell, Oxford.

Snijders, L.A., 1998, ' 'נַַח nahal', in G.J. Botterweck, H. Ringgren \& H.-J. Fabry (eds.), Theological dictionary of the Old Testament, vol. IX, transl. D.E. Green, pp. 335-340, Eerdmans, Grand Rapids, MI.

Staubli, T. \& Schroer, S., 2014, Menschenbilder der Bibel, Patmos Verlag, Ostfildern.

Tov, E., 2001, Textual criticism of the Hebrew Bible, 2nd edn., Fortress Press, Minneapolis, MN.

Tabakowska, E., 2013, '(Cognitive) grammar in translation: Form as meaning', in A. Rojo \& I. Ibarretxe-Antuñano (eds.), Cognitive linguistics and translation: Advances in some theoretical models and applications, pp. 229-249, De Gruyter Mouton, Berlin.
Tyler, A. \& Evans, V., 2003, The semantics of English prepositions: Spatial scenes, embodied meaning and cognition, Cambridge University Press, Cambridge.

Van der Merwe, C.H.J., 2006, 'Biblical exegesis, cognitive linguistics and hypertext', in A. Lemaire, (ed.), Congress volume Leiden 2004, pp. 255-280, Leiden, Brill.

Van der Merwe, C.H.J., 2012, 'The Bible in Afrikaans. A direct translation - a new type of Church Bible', Hervormde Teologiese Studies 68, Art. \#1204, 1208 pages. http:// dx.doi.org/1210.4102/hts.v1268i1201.1204

Van der Merwe, C.H.J., 2014, 'Direkte vertaling van die Bybel as antieke teks: Net 'n nuwe benaming vir'n stokkerige woordelikse vertaling?', LitNet Akademies, $11 \mathrm{Dec}$

Van der Merwe, C.H.J. \& Basson, C.S., 2003, "n Nuwe vertaling van die Bybel in Afrikaans. 'n Teoretiese en praktiese oriëntering', Nederduits Gereformeerde Teologiese Tydskrif 44(3-4), 550-567.

Van der Merwe, C.H.J. \& Van Rensburg, A., 2007, "n Nuwe vertaling van die Bybel in Afrikaans: Die praktiese aanvaarbaarheid van 'n nuwe vertaalmodel', Nederduits Gereformeerde Teologiese Tydskrif 48(1-2), 270-285.

Van der Merwe, C.H.J. \& Wendland, E., 2010, 'Marked word order in the book of Joel', Journal of Northwest Semitic Languages, 36(2), 255-80.

Van der Toorn, K., Becking, B. \& Van der Horst, P.W., (eds.), 1999, Dictionary of deities and demons in the Bible, 2nd edn., Brill, Leiden.

Van der Woude, A.S., 1997, 'צָּ șābā' army', in E. Jenni \& C. Westermann, (eds.) Theological lexicon of the Old Testament, pp. 1039-1046, Hendrickson Publishers, Peabody, MA.

Wagner, A., 2014, 'Das synthetische Bedeutungsspektrum hebräischer Körperteilbezeichnungen', in K. Müller \& A. Wagner (eds.), Synthetische Körperauffassung im hebräischen und den Sprachen der Nachbarkulturen pp. 1-11, Ugarit Verlag, Münster. (Alter Orient und Altes Testament, 416).

Wendland, E.R., 2008, Contextual frames of reference in translation: A coursebook for bible translators and teachers, St. Jerome Publishing, Manchester.

Wenham, G.J., 1998, Genesis 1-15, Word Books, Dallas, TX. (WBC 1).

Westermann, C., 1994, Genesis 1-11, Fortress Press, Minneapolis, MN. (A Continental Commentary)

Wilt, T. \& Wendland, E.R., 2008, Scripture frames \& framing, SUN Press, Stellenbosch.

Zobel, 1998, 'חס hesed', in G. Botterweck \& H. Ringgren (eds.), Theological dictionary of the Old Testament, vol. v, transl. D.E. Green, pp. 44-64, Eerdmans, Grand Rapids, MI. 